\title{
最近の研究
}

\section{ゾルーゲル法による $\mathrm{Y}-\mathrm{Ba}-\mathrm{Cu}-\mathrm{O}$ 系超伝導体の作製}

\section{1.はじめに}

金属アルコキシドあるいは金属塩を出発原料としてガ ラスやセラミックスを合成するいわゆるゾルーゲル法は, 液体急冷法や固相反応法などにない多くの特徵をむって いる(1). したがっててのゾルーゲル法の特長を生かすて とができれば, 理化学用ガラス器具と電気炉という最小 限の設備を使って, 均質性の高い超伝導体焼成前駆体や 超伝導コーティング膜, 超伝導ファイバーを作ることが 可能なはずである. 当初, ゾルーゲル法は水を添加物と して使用することが多いため，酸化物超伝導体を作製す るには適さないという議論ああったが，乙の 1 年半のあ いだに多くの研究成果があげられ，ゾルーゲル法による 酸化物超伝導体，とくにコーティング膜とファイバーの 作製が原理的に可能であることが示されてきた。 それと 同時に, このプロセシングがかかえる問題点やむずかし さあ次第に明らかになってきたように思われる。

本稿ではゾルーゲル法を使った $\mathrm{Y}-\mathrm{Ba}-\mathrm{Cu}-\mathrm{O}$ 系超伝 導体の合成の実例を著者らの成果を含めて紹介し, 現時 点でのこの方法の可能性と問題点を明らかにする.

\section{2. アルコキシド溶液の作製}

ゾルーゲル法では出発原料として金属アルコキシドを 使用することが理想的であるが(1)，銅のアルコキシドは アルコールに不溶性の固体である.そ乙で著者らはまず, 銅アルコキシドを酢酸銅 $\mathrm{Cu}\left(\mathrm{CH}_{3} \mathrm{COO}\right)_{2}$ または銅アセ チルアセトネート $\mathrm{Cu}\left(\mathrm{CH}_{3} \mathrm{COCHCOCH}_{3}\right)_{2}$ で代替して 均一溶液を作製することを試みたが， $\mathrm{Ba}\left(\mathrm{OC}_{4} \mathrm{H}_{9}{ }^{\mathrm{n}}\right)_{2}$ お よび $\mathrm{Y}\left(\mathrm{OC}_{4} \mathrm{H}_{9}{ }^{\mathrm{n}}\right)_{3}$ のアルコールーキシレン溶液にこれ

* 京都大学助手; 化学研究所

** 京都大学教授; 化学研究所

Preparation of Y-Ba-Cu-O Superconductor by SolGel Method ; Hiromitsu Kozuka, Sumio Sakka (Institute for Chemical Research, Kyoto Univ., Uji)

Keywords: superconductor, sol-gel method, fiber, coating film, low temperature synthesis 1988 年 8 月 17 日受理
幸 塚 広 光* 作 花 済 夫**

らの銅塩のアルコール溶液を加えると, 銅イオンがアル コキシドイオン $\mathrm{C}_{4} \mathrm{H}_{9} \mathrm{O}^{-}$の攻撃を受け, $\mathrm{Cu}\left(\mathrm{OC}_{4} \mathrm{H}_{9}{ }^{\mathrm{n}}\right)_{2}$ が析出してしまうことがわかった。

次に著者らは図 1 亿示す手順で, 銅メトキシド $\mathrm{Cu}$ $\left(\mathrm{OCH}_{3}\right)_{2}$ をトリエタノールアミンとメタノールからな る溶液にとかすことによって, $\mathrm{Y}-\mathrm{Ba}-\mathrm{Cu}$ 系アルコキ シド溶液が作製できることを見出した ${ }^{(2)}$. この場合，高 い塩基性をあつトリエタノールアミンが銅に部分的に配 位するてとによって溶解を助けているものと推察される. 表 1 亿示すように, 同様の方法としてジェチレントリア ミン $\left(\mathrm{NH}_{2} \mathrm{CH}_{2} \mathrm{CH}_{2}\right)_{2} \mathrm{NH}$ を使用した例がある(3).

このほか,アルコキシドとしてエトキシエトキシ ド $\mathrm{M}\left(\mathrm{OC}_{2} \mathrm{H}_{4} \mathrm{OC}_{2} \mathrm{H}_{5}\right)_{n}$ またはメトキシエトキシド $\mathrm{M}$ $\left(\mathrm{OC}_{2} \mathrm{H}_{4} \mathrm{OCH}_{3}\right)_{n}$ を使用し，メトキシェタノールまたは エトキシエタノールを溶媒として溶液を作った例があ $ろ^{(4)(5)}$. また, アルコキシドーブタノール混合物を不均 一系のままで加水分解させ，焼成前駆体粉末を作った例 もある(6).

\section{3. 有機酸塩の利用}

アルコキシドの加水分解・重合反応によらずにゲル

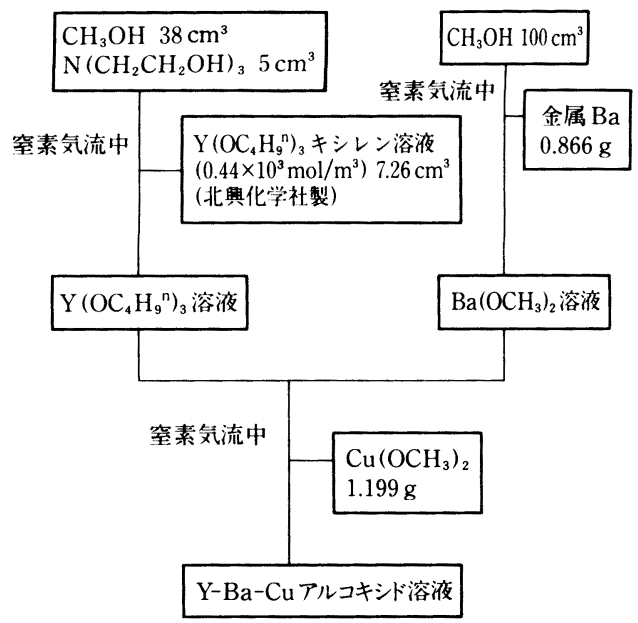

図1トリエタノールアミンを利用したアルコキシ ド溶液の作製. 
表 $1 \quad \mathrm{Y}-\mathrm{Ba}-\mathrm{Cu}-\mathrm{O}$ 系ゲルの作製例.

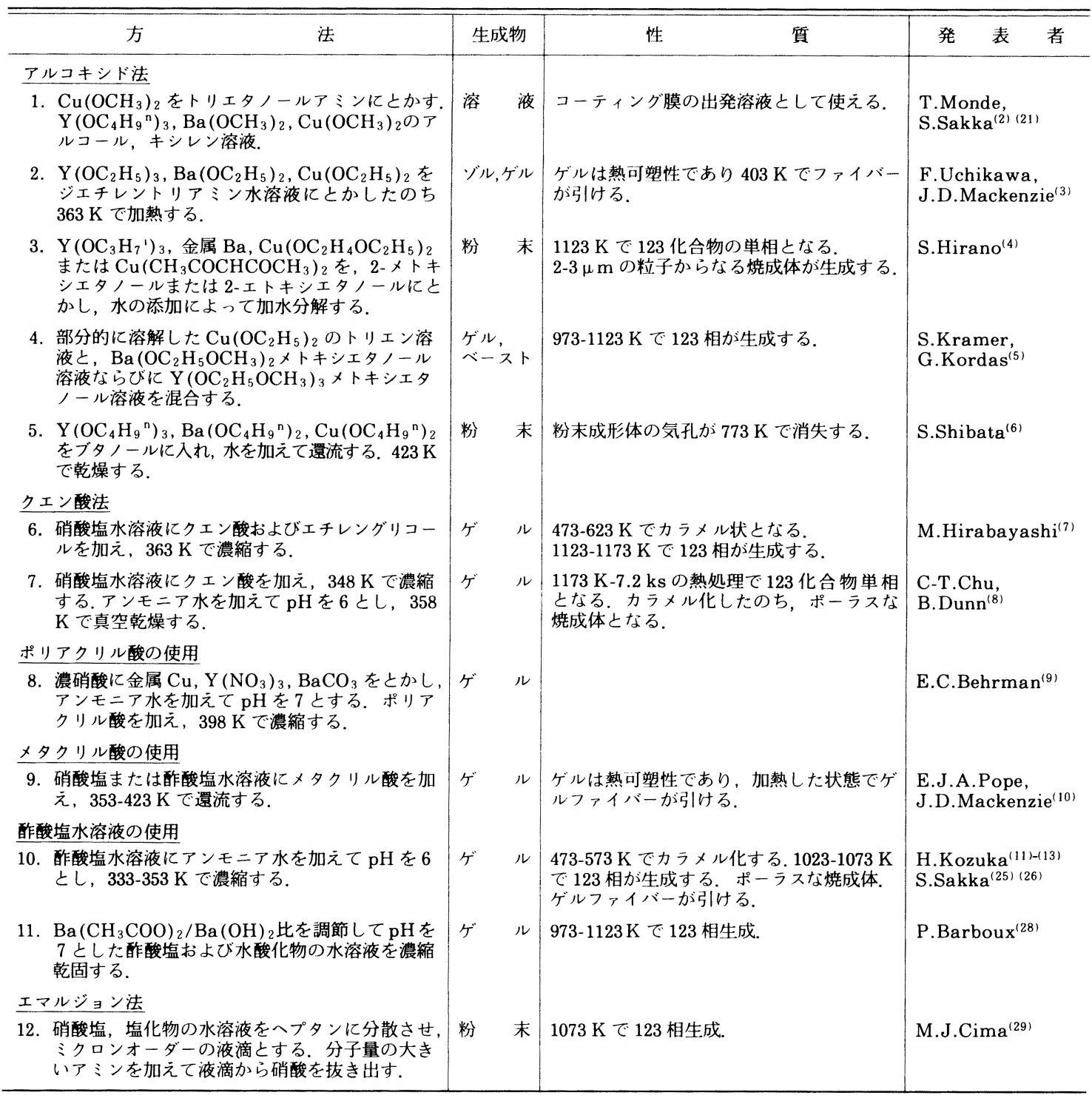

を作る試みがなされている。その1つであるクエン酸 法 $^{(7)(8)}$ (表 1)は, 金属イオンにクエン酸 $\mathrm{HOOCCH} \mathrm{CH}_{2} \mathrm{C}$ $(\mathrm{OH}) \mathrm{CH}_{2} \mathrm{COOH}$ のカルボキシル基を配位させ, クエン 酸とエチレングリコール $\mathrm{HOCH}_{2} \mathrm{CH}_{2} \mathrm{OH}$ などの溶媒に よって形成されるゲルマトリックスに金属イオンが均一 に分散した状態を作るあのである.ポリアクリル酸 $\left(\mathrm{CH}_{2} \mathrm{CH}(\mathrm{COOH})\right)_{n}$ を金属塩水溶液に添加する方法 ${ }^{(9)}$ や, 金属メタクリル酸塩 $\mathrm{M}\left(\mathrm{CH}_{2}=\mathrm{C}\left(\mathrm{CH}_{3}\right) \mathrm{COO}\right)_{n}$ を $\mathrm{C}=\mathrm{C}$ 結合の開裂によって重合させる方法 ${ }^{(10)}$ も, クエン 酸法之同様に, カルボキシル基による金属イオンへの配 位と, 有機物による金属イオン間の連結を利用した方法 とみなすことができる。

著者らは金属酢酸塩の水溶液にアンモニア水を加えて
$\mathrm{pH}$ を 6 に調整したものを 333 〜 $353 \mathrm{~K}$ で濃縮すること によって, $\mathrm{Y}: \mathrm{Ba}: \mathrm{Cu}=1: 2: 3$ の組成をむつ青色透明 ゲルが生成することを見出した ${ }^{(11)}$ (図 2). ゲルの赤外吸 収スペクトルを测定したところ， $600 \mathrm{~cm}^{-1}$ 以下の低波 数域での吸収が認められないことから，ゲル中では金属 酸素 - 金属結合が形成されていないてとがわかった。

有機酸や有機酸塩を利用する以上の方法で合成された ゲルを焼成すると, $473 \sim 573 \mathrm{~K}$ の温度で激しい発泡や力 ラメル化が観察されるととが多い. アルコキシドの加水 分解・脱水縮合による場合と異なり, 金属イオン間の結 合が有機物イオンを介した弱い結合であることが, 発泡・ カラメル化をおこしやすくしているものと考えられる. 


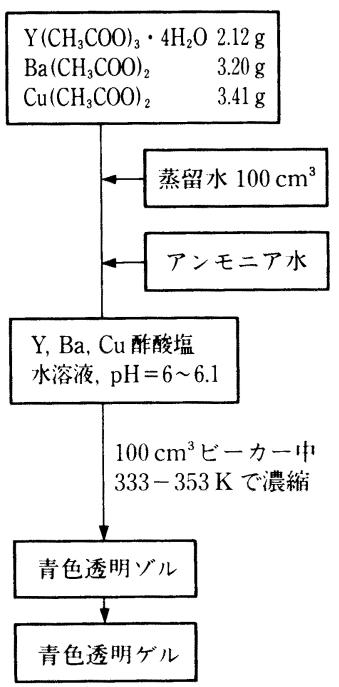

図 2 酢酸塩水溶液からのゲルの作製.

\section{4. ゲルの熱処理による $\mathrm{YBa}_{2} \mathrm{Cu}_{3} \mathrm{O}_{7-x}$ 相の生成}

表 1 に示すように，ゲルの熱処理過程では 973〜1123 $\mathrm{K}$ という低い温度で $\mathrm{YBa}_{2} \mathrm{Cu}_{3} \mathrm{O}_{7-x}$ 相が生成する場合 が多い。著者らが作製した酢酸塩ゲルでは 1023〜1073 $\mathrm{K}$ で $\mathrm{YBa}_{2} \mathrm{Cu}_{3} \mathrm{O}_{7-x}$ の生成が認められ(図 3), ゲル片 を $83.3 \times 10^{-3} \mathrm{~K} / \mathrm{s}\left(5^{\circ} \mathrm{C} / \mathrm{min}\right)$ で $1183 \mathrm{~K}$ まで昇温し， 18 $\mathrm{ks}$ 熱処理したのち炉中放冷して得られた多孔質焼成体 では $T_{\mathrm{c}}(\mathrm{end})=93 \mathrm{~K}$ の超伝導転移が認められた ${ }^{(11)}$.

しかし，昇温過程でゲルから $\mathrm{YBa}_{2} \mathrm{Cu}_{3} \mathrm{O}_{7-x}$ 相が初 相として析出したとの報告は見当たらない，著者らの作製 した酢酸塩ゲルは, 昇温過程で $\mathrm{Cu}, \mathrm{Cu}_{2} \mathrm{O}, \mathrm{Ba}(\mathrm{OH})_{2}$ の析出を経たのち $723 \mathrm{~K}$ 以上の温度で $\mathrm{Y}_{2} \mathrm{O}_{3}, \mathrm{BaCO}_{3}$, $\mathrm{CuO}$ の混合物となる ${ }^{(12)}$ 。また，ゲルからの $\mathrm{YBa}_{2}$ $\mathrm{Cu}_{3} \mathrm{O}_{7-x}$ 相の生成が抢こる 973〜 $1123 \mathrm{~K}$ という温度を 熱処理の最高温度として作製した焼成体で $T_{\mathrm{c}}(\mathrm{end})>$ $90 \mathrm{~K}$ の超伝導転移が認められたとの報告が見られず， 前述の酢酸塩ゲルを $1073 \mathrm{~K}$ で焼成したものは，X 線的 には $\mathrm{YBa}_{2} \mathrm{Cu}_{3} \mathrm{O}_{7-x}$ 相が認められるにもかかわらずそ の電気抵抗の温度変化は半導体的であり, 超伝導転移が 観察されなかった ${ }^{(12)(13)}$ 。乙れらの温度を熱処理の最高 温度とする焼成体の $\mathrm{X}$ 線回折パターンには, 斜方晶 $\mathrm{YBa}_{2} \mathrm{Cu}_{3} \mathrm{O}_{7-x}$ または正方晶 $\mathrm{YBa}_{2} \mathrm{Cu}_{3} \mathrm{O}_{7-x}$ に特有の ピークの分裂が欠如しているてとがしばしば指摘されて おり，しかも， $1173 \mathrm{~K}$ 以上の温度で焼成したものと 1073 $\mathrm{K}$ で焼成したものでは, 微細構造にも著しい違いが認 められることが多い(13).

これらのことが，熱処理温度が低いために単に生成物 の結晶性が悪いことによるのか, いわゆる斜方晶 $\mathrm{YBa}_{2}$ $\mathrm{Cu}_{3} \mathrm{O}_{7-x}$, 正方晶 $\mathrm{YBa}_{2} \mathrm{Cu}_{3} \mathrm{O}_{7-x}$ とは異なった構造をも

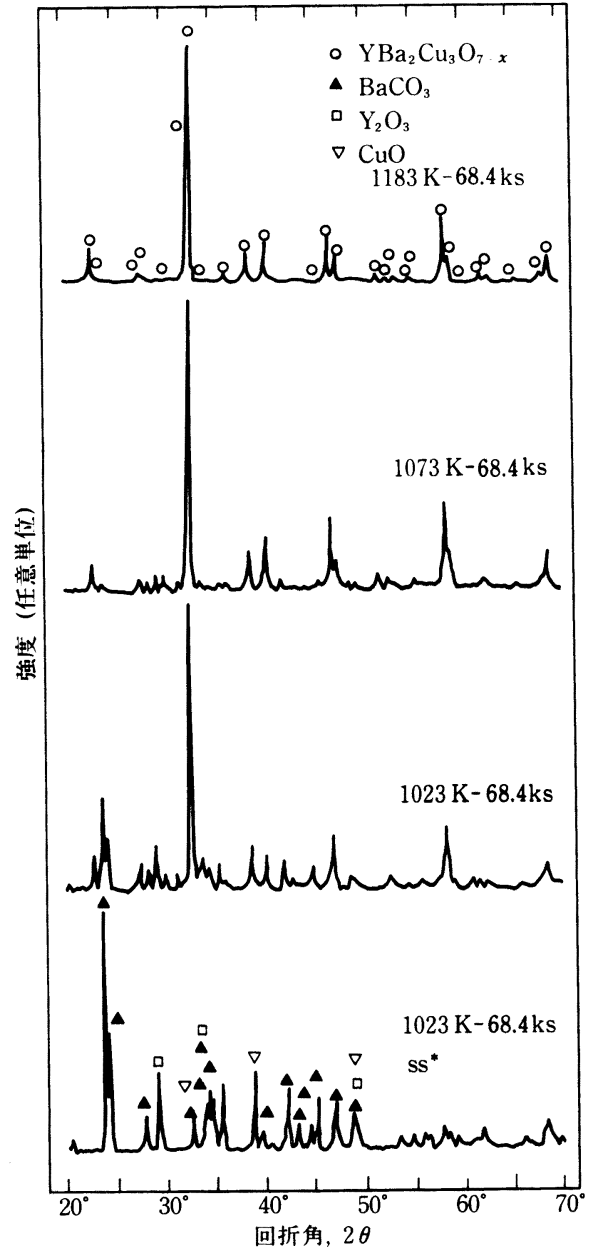

図 3 酢酸塩水溶液 $(\mathrm{Y}: \mathrm{Ba}: \mathrm{Cu}=1: 2: 3)$ 加ら作 製したゲルの熱処理後の X 線回折パターン; 昇温速度, $83.3 \times 10^{-3} \mathrm{~K} / \mathrm{s}$ : 保持時間, 68.4 $\mathrm{ks}(19 \mathrm{~h})\left(\mathrm{ss}^{*}: \mathrm{Y}_{2} \mathrm{O}_{3}, \mathrm{BaCO}_{3}, \mathrm{CuO}\right.$ 粉末を 用いた固相反応で得た焼結体).

つ $\mathrm{YBa}_{2} \mathrm{Cu}_{3} \mathrm{O}_{7-x}$ 相がこの温度域に存在する ${ }^{(14)}$ ととに よるのかは, 今のとてろ明らかでない。

\section{5. コーティング膜}

表 2 亿示すように, 有機酸塩 ${ }^{(15)-(20)}$, アルコキシ $ト^{(2)(5)(6)(21)}$, 硝酸塩 ${ }^{(22)(23)}$ を出発物質とする超伝導コ一 ティング膜が作製されている．著者らは，3.で述べたア ルコキシド溶液を YSZ 基板上に滴下し，ホットプレー ト上で乾燥してゲル膜としたものを $1073 \mathrm{~K}$ で $0.3 \mathrm{ks}$ 間 熱処理し, 滴下・乾燥・熱処理の操作を 5 10 回繰り返 したのち $1073 \mathrm{~K}$ 酸素気流中で $288 \mathrm{ks}(80 \mathrm{~h})$ 熱処理し, 炉中放冷することによってコーティング膜を作製し た ${ }^{(2)(21)}$. 厚さ $1.5 \sim 7 \mu \mathrm{m}$ の膜は, $T_{\mathrm{c}}$ (onset) $=98 \mathrm{~K}$, $T_{\mathrm{c}}(\mathrm{end})=56 \mathrm{~K}$ の超伝導転移を示した. 
表 2 ゾルーゲル法による $\mathrm{YBa}_{2} \mathrm{Cu}_{3} \mathrm{O}_{7-x}$ コーティング膜の作製例.

\begin{tabular}{|c|c|c|c|c|c|c|c|c|c|}
\hline \multirow{2}{*}{ 出 発 物 質 } & \multirow{2}{*}{ 溶媒 } & \multirow{2}{*}{ 方法 } & \multirow{2}{*}{ 基 } & \multirow{2}{*}{$\begin{array}{c}\text { 膜厚 } \\
(\mu \mathrm{m})\end{array}$} & \multirow{2}{*}{$\begin{array}{l}\text { 使用最高 } \\
\text { 温 } \\
\quad(\mathrm{K})\end{array}$} & \multicolumn{2}{|c|}{$T_{\mathrm{c}}(\mathrm{K})$} & \multirow{2}{*}{ 配向 } & \multirow{2}{*}{ 発 表 者 } \\
\hline & & & & & & onset & end & & \\
\hline \multicolumn{10}{|l|}{ 有機酸塩 } \\
\hline $\begin{array}{l}\text { 1. ステアリン酸塩 }(\mathrm{Y}), \\
\text { ナフテン酸塩 }(\mathrm{Ba}, \mathrm{Cu})\end{array}$ & n-ブタノール & 滴下 & YSZ & $1-3$ & 1073 & 90 & 60 & & T.Kumagai ${ }^{(15)}$ \\
\hline 2. 2-エチルヘキサン酸塩 & トルエン & 滴下 & YSZ & 10 & 1173 & 100 & 82 & & H.Nasu ${ }^{(16)}$ \\
\hline 3. 2-エチルヘキサン酸塩 & クロロホルム & スピンコート & $\mathrm{MgO}$ & 1.4 & 1263 & 89 & 77 & $(001)$ & M.E.Gross ${ }^{(17)}$ \\
\hline $\begin{array}{l}\text { 4. } \begin{array}{l}\text { ネオデカン酸塩 } \\
\text { オクタン酸塩 }\end{array}\end{array}$ & キシレン & スピンコート & Si ウェーハー & $0.1-1$ & 1073 & 98 & 80 & $(110)$ & W.W.Davison ${ }^{(18)}$ \\
\hline 5. 酢酸塩 & 酢酸水溶液 & スピンコート & $\mathrm{MgO}$ 単結晶 & 0.16 & 1263 & 80 & 58 & & C.E.Rice ${ }^{(19)}$ \\
\hline 6. クエン酸塩 & $\begin{array}{l}\text { エチレン } \\
\text { グリコール }\end{array}$ & スピンコート & $\begin{array}{l}\mathrm{SrTiO}_{3} \text { 単結晶 } \\
\text { ( (100) 面配向 })\end{array}$ & 0.5 & $1073-1173$ & 60 & - & $(001)$ & Y.M.Chiang ${ }^{(20)}$ \\
\hline \multicolumn{10}{|l|}{ アルコキシド } \\
\hline 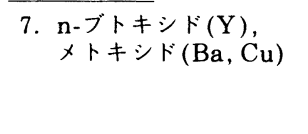 & $\begin{array}{l}\text { メタノール, } \\
\text { キシレン, } \\
\text { トリエタノー } \\
\text { ルアミン }\end{array}$ & 滴下 & YSZ & $1.5-7$ & 1073 & 98 & 56 & & $\begin{array}{l}\text { T.Monde, } \\
\text { S.Sakka }\end{array}$ \\
\hline $\begin{array}{l}\text { 8. メトキシェトキシド } \\
(\mathrm{Y}, \mathrm{Ba}), \text { エトキシド } \\
(\mathrm{Cu})\end{array}$ & $\begin{array}{l}\text { メトキシエタ } \\
\text { ノール } \\
\text { トルエン }\end{array}$ & ディッピング & $\begin{array}{l}\text { Si 単結晶 } \\
\text { ((100)面配向) }\end{array}$ & $\begin{array}{l}0.15- \\
1.0\end{array}$ & 973 & $(40)$ & - & & $\begin{array}{l}\text { S.Kramer, } \\
\text { G.Kordas }^{(5)}\end{array}$ \\
\hline 9. n-ブトキシド & $\begin{array}{l}\text { n-ブタノール, } \\
\text { 水(ペースト) }\end{array}$ & 塗布 & YSZ & $5-10$ & $1193-1223$ & & 80 & (001) & S.Shibata ${ }^{(6)}$ \\
\hline \multicolumn{10}{|l|}{ 無機塩 } \\
\hline 10. 硝酸塩 & $\begin{array}{l}\text { 硝酸水溶液, } \\
\text { エタノール }\end{array}$ & スプレー & $\begin{array}{l}\mathrm{YSZ}, \\
\mathrm{SrTiO}_{3}(100), \\
\mathrm{MgO}(100)\end{array}$ & - & $1200-1220$ & $\begin{array}{l}95 \\
89 \\
84\end{array}$ & $\begin{array}{l}89 \\
81 \\
79\end{array}$ & & E.I.Cooper ${ }^{(22)}$ \\
\hline 11. 硝酸塩 & トルエン & 滴下 & YSZ & - & 1173 & 93 & 63 & & H.Nasu ${ }^{(23)}$ \\
\hline
\end{tabular}

表 2 のコーティング膜作製例に見られるように，焼成 過程での基板と膜の反応の影響を小さくするため，1〜 $10 \mu \mathrm{m}$ の厚い膜を, 溶液の滴下・塗布などのコーティ ング操作によって作った例が多いようである.ディップ コーティングを繰り返して膜厚を増す方法 ${ }^{(1)}$ では, 溶液 の $\mathrm{pH}$ や成分によっては一旦生成した $\mathrm{YBa}_{2} \mathrm{Cu}_{3} \mathrm{O}_{7-x}$ から一部の成分が浸漬液中に溶出し ${ }^{(24)}$, 膜の組成が変 化することがあるので，注意する必要がある.

焼成温度を低くすることによって膜と基板の反応速度 を小さくすることができるが，乙の場合には超伝導相の 生成が十分にはおこりにくくなる．著者らの方法では $1173 \mathrm{~K}$ で基板と膜の反応により $\mathrm{BaZrO}_{3}$ が生成するた め ${ }^{(21)}$, 焼成最高温度を $1073 \mathrm{~K}$ としたが, 十分高い $T_{\mathrm{c}}$ が得られなかった。 しかし表 2 に見られるように，1173 $\mathrm{K}$ 以上の高温で短時間の熱好理を行うことによって $T_{\mathrm{c}}$ (end) $>80 \mathrm{~K}$ の超伝導膜を作ったという報告むある.

表 2 に示すように，1173〜 $1263 \mathrm{~K}$ の高温で熱処理 したもので配向した膜が得られたとの報告がある が(6)(17)(20)，乙れらの膜作製過程では膜の融解がおこっ ているのではないかと著者らは考えている，融解を経る ことなく，ゲル膜から配向した結晶粒子をより低い温度 で直接析出させることができるかどうかは今のところ不 明である。
6. ファイバー

表 3 亿示すように，高粘性ゾルからのゲルファイバー

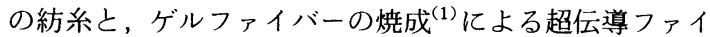
バーの作製が試みられている。

著者らは，前述の酢酸塩水溶液から作製した高粘性の ゾルからゲルファイバーを紡糸し，ゲルファイバーを焼 成することによって太さ $5 \mu \mathrm{m}-1 \mathrm{~mm}$ の $\mathrm{YBa}_{2} \mathrm{Cu}_{3}$ $\mathrm{O}_{7-x}$ セラミックファイバーを作製した ${ }^{(12)(13)(25)(26)}$ (図 4). ゲルファイバーは 473〜 $573 \mathrm{~K}$ の温度で発泡し，乙れに よって生成する中空構造が $1173 \mathrm{~K}$ 以上の高温まで残る ため, 生成するセラミックファイバーは脆い。発泡の程 度を小さくするためには，有機酸を介した結合ではなく， 金属 - 酸素 - 金属結合を骨格亡するゾルからの紡系が必 要であると考えられる.

Mackenzie らのグループでは，アルコキシド溶液ま たはメタクリル酸塩溶液から合成したゾルからゲルファ イバーを紡系し，ゲルファイバーを焼成して $\mathrm{YBa}_{2} \mathrm{Cu}_{3}$ $\mathrm{O}_{7-x}$ セラミックファイバーを作製しているが(3)(10)，乙 れらのファイバーでも焼成過程での発泡と中空構造の形 成が見られ，生成するファイバーは脆い，組成の均一な ゾルからの直接紡系による方法ではないが, 後藤ら ${ }^{(27)}$ 
表 3 ゾル -ゲル法による $\mathrm{YBa}_{2} \mathrm{Cu}_{3} \mathrm{O}_{7-x}$ ファイ バーの作製例。

\begin{tabular}{|c|c|c|c|c|c|}
\hline \multirow{2}{*}{$\begin{array}{l}\text { ゾル作製のた } \\
\text { めの出発溶液 }\end{array}$} & \multirow{2}{*}{$\begin{array}{l}\text { ファイ } \\
\text { バーの } \\
\text { 直径 }\end{array}$} & \multicolumn{2}{|c|}{$T_{\mathrm{c}}(\mathrm{K})$} & \multirow{2}{*}{$\begin{array}{c}\text { 熱好理 } \\
\text { 最 } \\
\text { 䯩 } \\
\text { 温 度 } \\
(\mathrm{K})\end{array}$} & \multirow{2}{*}{ 表 } \\
\hline & & onset & end & & \\
\hline 酢酸塩水溶液 & $\begin{array}{l}5 \mu \mathrm{m}- \\
1 \mathrm{~mm}\end{array}$ & 90 & 73 & 1223 & $\begin{array}{l}\text { S.Sakka, } \\
\text { H.Kozuka }\end{array}$ \\
\hline $\begin{array}{l}\text { アルコキシド } \\
\text { のジェチレン } \\
\text { トリアミン水 } \\
\text { 溶液 }\end{array}$ & $100 \mu \mathrm{m}$ & 90 & 80 & 1223 & $\begin{array}{l}\text { F.Uchikawa, } \\
\text { J.D.Mackenzie }\end{array}$ \\
\hline $\begin{array}{l}\text { メタクリル酸 } \\
\text { 塩溶液 }\end{array}$ & & & & 1173 & $\begin{array}{l}\text { E.J.A.Pope, } \\
\text { J.D.Mackenzie }\end{array}$ \\
\hline
\end{tabular}
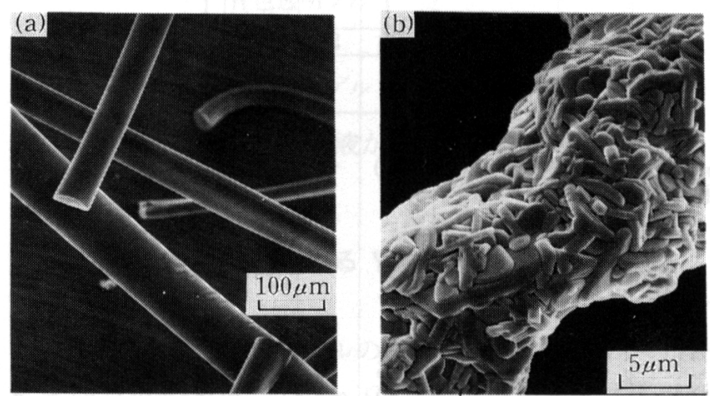

図 4 酢酸塩ゾルから紡系したゲルファイバー (a), な らびにゲルファイバーを $83.3 \times 10^{-3} \mathrm{~K} / \mathrm{s}$ で $1223 \mathrm{~K}$ まで昇温して作製した $\mathrm{YBa}_{2} \mathrm{Cu}_{3} \mathrm{O}_{7-x}$ ファイバー (b)の SEM 写真.

は, $\mathrm{YBa}_{2} \mathrm{Cu}_{3} \mathrm{O}_{7-x}$ 粉末にポリビニルアルコールを含浸 させて焼成する方法で, $37 \mathrm{MPa}$ の引張り強さをもつファ イバーを作製している.

\section{7. おわりに}

我々が理想とするゾルーゲルプロセスは，ガラスの合成 で経験してきたような金属 - 酸素 - 金属結合を骨格とす るゲル成形体(バルク，ファイバー，コーティング膜)の 焼結による $\mathrm{YBa}_{2} \mathrm{Cu}_{3} \mathrm{O}_{7-x}$ 成形体の低温直接合成であ り，乙れによって緻密なファイバーやバルク体の作製が 可能なはずである.また, ゲルからの $\mathrm{YBa}_{2} \mathrm{Cu}_{3} \mathrm{O}_{7-x}$ 相の低温直接生成が可能となれば, 基板と膜の反応を気 にすることなく $\mathrm{YBa}_{2} \mathrm{Cu}_{3} \mathrm{O}_{7-x}$ 膜を作製することがで きるあのと考えられる.

超伝導酸化物の系において, ゾルあるいはゲルの状態 で金属 - 酸素 - 金属結合を骨格とするポリマーを合成す ることが可能であるかどうかを検討することが今後の重 要な課題である. そのためには, 出発原料の種類, 加水 分解のために加える水の量, 溶液の $\mathrm{pH}$, 反応温度なよ゙
を系統的に変化させ，生成物中のイオンの結合状態を調 ベていく必要があろう。

\section{文献}

（1）横尾俊信，神谷寛一，作花済夫：日本金属学会会報，27 (1988), 775.

( 2 ) T.Monde, H.Kozuka and S.Sakka : Chem. Lett., 1988 (1988), 287.

( 3 ) F.Uchikawa, H.Zheng, K.C.Chen and J.D.Mackenzie in "High Temperature Superconductors II", Ed. by D. W.Capone II, W.H.Butler, B.Batlogg and C.W.Chu, Materials Research Society, Pittsburg, (1988), 89.

(4) S.Hirano, T.Hayashi, R.H.Baney, M.Miura and H.Tomonaga : Chem. Lett., 1988(1988), 665.

( 5 ) S.Kramer, K.Wu and G.Kordas: Mat. Res. Soc. Symp. Proc., 99(1988), 323.

(6) S.Shibata, T.Kitagawa, H.Okazaki, T.Kimura and T.Murakami : Jpn. J. Appl. Phys., 27(1988), L53.

（7）平林正之: 日本金属学会会報, 26(1987), 943.

( 8 ) C.-T.Chu and B.Dunn : J. Am. Ceram. Soc., 70(1987), C357.

( 9 ) E.C.Behrman et al. : Adv. Ceram. Mater., 2(1987), 539

(10) E.J.A.Pope and J.D.Mackenzie : in "High Temperature Superconductors II", Ed. by D.W.Capone II, W.H. Butler, B.Batlogg and C.W.Chu, Materials Research Society, Pittsburg, (1988), 97.

(11) H.Kozuka, T.Umeda, J.S.Jin, F.Miyaji and S.Sakka : J. Ceram. Soc. Japan, 96(1988), 355.

(12) H.Kozuka, T.Umeda, J.S.Jin and S.Sakka : paper presented at Materials Research Society, 1988 Spring Meeting, Reno, April, (1988).

(13) S.Sakka, H.Kozuka, T.Umeda and J.S.Jin : paper presented at MRS International Meeting on Advanced Materilas, Tokyo, (1988).

(14) A. Manthiram and J. B. Goodenough : Nature, 329 (1987), 701.

(15) T.Kumagai, H Yokota, K.Kawaguchi, W.Kondo and S.Mizuta : Chem. Lett., 1987(1987), 1646.

(16) H.Nasu, S.Makida, T.Imura and Y.Osaka : to be published in J. Mater. Sic. Lett.

(17) M.E.Gross, M.Hong, S.H.Liou and P.K.Gallagher : Mat. Res. Soc. Symp. Proc., 99(1988), 731.

(18) W.W.Davison, S.G.Shyu and R.C.Buchanan : ibid., 99 (1988), 289.

(19) C.E.Rice, R.B.van Dover and G.J.Fisanick: Appl. Phys. Lett., 51(1987), 1842.

(20) Y. - M. Chiang, S. L. Furcone, J. A. S. Ikeda and S. A. Rudman : Mat. Res. Soc. Symp. Proc., 99(1988), 307.

(21) T. Monde and S. Sakka : paper presented at MRS International Meeting on Advanced Materials, Tokyo, (1988).

(22) E.I.Cooper, M.A.Frisch, E.A.Giess, A.Gupta, B.W Hussey, E.J.M.O'Sullivan, S.I.Raider and G.J.Scilla : Mat. Res. Soc. Symp. Proc., 99(1988), 165.

(23) H.Nasu, S.Makida, T.Imura and Y.Osaka : in "High Temperature Superconductors II", Ed. by D.W.Capone II, W.H.Butler, B.Batlogg and C.W.Chu, Materials Research Society, Pittsburg, (1988), 101.

(24) K.Komori, H.Kozuka and S.Sakka : to be published in J. Mater. Sci.

(25) S.Sakka, H.Kozuka and T.Umeda: J. Ceram. Soc. Japan, 96(1988), 468

(26) T.Umeda, H.Kozuka and S.Sakka : to be published in Adv. Ceram. Mater.

（27）後藤共子：酸化物超伝導体の化学，笛木和夫，北沢宏一 編, 講談社, 東京, (1988), 110.

(28) P.Barboux, J.M.Tarascon, B.G.Bagley, L.H.Greene, G.W.Hull, B.W.Meagher and C.B.Eom: Mat. Res. Soc. Symp. Proc., 99(1988), 49.

(29) M.J.Cima, R.Chiu and W.E.Rhine : ibid., 99(1988), 241. 